\title{
1 Plagioclase archives of depleted melts in the oceanic crust
}

2 David A. Neave ${ }^{1,2}$ and Olivier Namur ${ }^{3}$

$3{ }^{1}$ Department of Earth and Environmental Sciences, The University of Manchester, M13 9PL

4 Manchester, $U K$

$5 \quad{ }^{2}$ Leibniz Universität Hannover, Institut für Mineralogie, 30167 Hannover, Germany

$6{ }^{3}$ Department of Earth and Environmental Sciences, KU Leuven, BE-3001 Leuven, Belgium

\section{ABSTRACT}

8 Mid-ocean ridge and ocean island basalts provide vital but incomplete insights into mantle

9 chemistry. For example, high-anorthite plagioclase is generally too refractory and incompatible-

10 element depleted to have crystallized from the melts that carry it to the surface. Moreover,

11 erupted basalts rarely preserve the extreme isotopic and incompatible-element depletions found

12 in some primitive melt inclusions and residual abyssal peridotites. By integrating experimental

13 observations with analyses of natural crystals and glasses, we infer that high-anorthite

14 plagioclase grows from high-degree melts of refractory but otherwise unexotic mantle sources

15 with depleted incompatible element compositions. The widespread occurrence of high-anorthite

16 plagioclase in oceanic basalts and the oceanic crust hence indicates that refractory melts pervade

17 the uppermost mantle and lower crust. We thus suggest that refractory melts play much a greater

18 role in crustal accretion than typically recognized, and that refractory and feasibly depleted

19 peridotite is more prevalent in the upper mantle than previously thought. 
Preprint of a revised manuscript resubmitted to Geology and uploaded to EarthArXiv

\section{INTRODUCTION}

Mid-ocean-ridge and ocean-island basalts (MORB and OIB respectively; oceanic basalts collectively) provide important windows into the chemistry of Earth's mantle (Hofmann, 1997; Stracke, 2021). Over billions of years, lithospheric recycling at subduction zones has created chemically, isotopically and lithologically enriched mantle domains that are ultimately reflected in the compositions of erupted basalts (Chase, 1981). Concurrent melt extraction and crustal accretion has created refractory and depleted domains that are well documented in abyssal peridotites but rarely expressed in erupted records, reflecting the poor preservation of depleted melts (Salters et al., 2011; Byerly and Lassiter, 2014; Sanfilippo et al., 2021). Melt inclusions in primitive crystals, which are relatively resistant to mixing-induced overprinting, thus provide vital constraints on the chemical and isotopic variability of primitive melts and their mantle sources (Sobolev and Shimizu, 1993; Maclennan, 2008b, 2008a; Stracke et al., 2019). They are however challenging to analyze and remain susceptible to contamination by enriched melts in the deepest reaches of plumbing systems. Fortunately, crystals also record information about the melts from which they grow, and as volumetrically significant components of magmas and cumulates can reflect the abundance of chemically distinct melts at depth.

High-anorthite plagioclase $\left(X_{\mathrm{An}}>0.8\right.$, where $X_{\mathrm{An}}=$ molar $\left.\mathrm{Ca} /(\mathrm{Ca}+\mathrm{Na}+\mathrm{K})\right)$ is a major constituent of many basalts from ocean islands and slow- to intermediate-spreading mid-ocean ridges (Lange et al., 2013), as well as various cumulates from ophiolites and the lower oceanic crust (Browning, 1982; Lissenberg et al., 2013). However, such crystals are rarely in majorelement equilibrium with erupted basalts (cf. Natland et al., 1983). Moreover, they are often out of isotopic and incompatible-element equilibrium with their carrier melts, implying origins from different mantle melt distributions (Halldórsson et al., 2008; Neave et al., 2014; Nielsen et al., 
Preprint of a revised manuscript resubmitted to Geology and uploaded to EarthArXiv

43 2020). High- $X_{\text {An }}$ plagioclase cannot be reproduced in experiments on MORB starting

44 compositions with realistic volatile contents (Grove et al., 1992; Kohut and Nielsen, 2003), and

45 calculations with the MELTS algorithm indicate that primitive MORBs (MgO > 8 wt.\%)

46 typically saturate in $X_{\mathrm{An}}=0.75-0.80$ plagioclase (Ghiorso and Sack, 1995; Neave et al., 2019).

47 High- $X_{\text {An }}$ plagioclase crystals in oceanic settings are hence thought to grow from refractory,

48 high-Ca\# melts (where $\mathrm{Ca} \#=$ molar $\mathrm{Ca} /(\mathrm{Ca}+\mathrm{Na})$ ) with high solidus and liquidus temperatures

49 that seldom erupt (Grove et al., 1992; Neave et al., 2019). Here we integrate observations from

50 natural and experimental systems to explore the origins of high- $X_{\text {An }}$ plagioclase crystals in

51 oceanic settings and discuss the role that high-Ca\# melts play in oceanic magmatism.

\section{PLAGIOCLASE-LIQUID EQUILIBRIA}

53 The exchange of anorthite $\left(\mathrm{An} ; \mathrm{CaAl}_{2} \mathrm{Si}_{2} \mathrm{O}_{8}\right)$ and albite $\left(\mathrm{Ab} ; \mathrm{NaAlSi}_{3} \mathrm{O}_{8}\right)$ components

54 between liquid and plagioclase depends on many variables (Namur et al., 2012, and references

55 therein). In summary, equilibrium plagioclase $X_{\text {An }}$ correlates positively with melt Ca\#, melt Al\#

56 (where $\mathrm{Al} \#=$ molar $\mathrm{Al} /(\mathrm{Al}+\mathrm{Si})$ ), melt $\mathrm{H}_{2} \mathrm{O}$ content and temperature, and negatively with

57 pressure. The melt $\mathrm{H}_{2} \mathrm{O}$ content of oceanic basalts is uniformly low when compared with arc

58 basalts ( $\leq 1 \mathrm{wt.} \%$; Michael, 1995), and thus exerts little influence over plagioclase $X_{\text {An }}$.

59 Conversely, melt Ca\#, which varies greatly in oceanic basalts, is inextricably linked with

60 equilibrium $X_{\mathrm{An}}$ and the timing of plagioclase saturation (Bowen, 1913). For example,

61 observations from experiments on synthetic analogues of Icelandic lavas at $300 \mathrm{MPa}$

62 demonstrate that plagioclase saturates at higher melt $\mathrm{MgO}$ contents and temperatures, and with

63 higher $X_{\text {An }}$ contents, during the crystallization of high-Ca\# primitive melts from depleted

64 peridotite sources with refractory major element compositions than during the crystallization of

65 low-Ca\# primitive melts from modally enriched sources with more fusible compositions (Neave 
Preprint of a revised manuscript resubmitted to Geology and uploaded to EarthArXiv

et al., 2019). To place these observations within the polybaric context of crustal magmatism, we performed new crystallization experiments on the same lava analogues from Iceland at 100 and $600 \mathrm{MPa}$ (high-Ca\# Háleyjabunga lava, refractory source; low-Ca\# Stapafell lava, fusible source; details in the Supplementary Material).

Plagioclase-liquid equilibria at 100 and $600 \mathrm{MPa}$ are summarized in Fig. 1 alongside published equilibria at $300 \mathrm{MPa}$ from Neave et al. (2019). The high-Ca\# Háleyjabunga analogue saturates in plagioclase at higher melt $\mathrm{MgO}$ contents (and temperatures) than the low-Ca\# Stapafell analogue. While isobaric differences in plagioclase saturation between the two starting compositions reflect mantle-derived variability in melt Ca\# and Al\#, polybaric differences reflect differences in plagioclase and clinopyroxene stability, with plagioclase generally saturating at lower temperatures (and melt $\mathrm{MgO}$ contents) when clinopyroxene stability is greater at higher pressures (Fig. 1). Equilibrium plagioclase $X_{\mathrm{An}}$ also correlates negatively with clinopyroxene stability and pressure. Overall, melt composition, which correlates with pressure and temperature as well as source composition, exerts the main control over $X_{\mathrm{An}}$, with high- $X_{\mathrm{An}}$ plagioclase only crystallizing from the high-Ca\# Háleyjabunga analogue (up to $X_{\mathrm{An}}=0.88$ and 0.85 in the products of 100 and $300 \mathrm{MPa}$ experiments, respectively; the highest $X_{\mathrm{An}}$ crystallized from lowCa\# Stapafell analogue was 0.71). Importantly, our new experiments demonstrate that high- $X_{\mathrm{An}}$ plagioclase can be produced from refractory oceanic basalts under realistic pressure and temperature conditions (cf. Grove et al., 1992; Kohut and Nielsen, 2003). Even if the composition of Háleyjabunga lava is at the limit of erupted variability (Fig. 3), our findings thus suggest high- $X_{\text {An }}$ plagioclase crystals reflect the crystallization of refractory but essentially unexotic melts derived from refractory mantle sources that experienced high degrees of prior melt extraction, whether recent or ancient. 
Preprint of a revised manuscript resubmitted to Geology and uploaded to EarthArXiv

\section{PREDICTING PLAGIOCLASE-LIQUID EQUILIBRIA}

By predicting equilibrium plagioclase $X_{\mathrm{An}}$ as a function of melt composition it is possible to evaluate plagioclase-liquid equilibria in diverse natural systems. While thermodynamic models allow phase relations to be extrapolated across wide parameter spaces (Ghiorso and Sack, 1995; Holland et al., 2018), empirical models can be more precise when applied within their calibration ranges (e.g., Namur et al., 2012). Moreover, it is possible to avoid introducing erroneous assumptions about crystallization conditions by predicting equilibrium $X_{\mathrm{An}}$ from melt compositions alone; pressure and temperature are implicit in melt compositions.

Performing multiple linear regression through calibration data $(n=98)$ from experimental studies on basalts from mid-ocean ridges, an oceanic plateau and an ocean island yields the following relationship between plagioclase $X_{\mathrm{An}}$ and melt composition (Fig. 2a; $r^{2}=0.88$; standard error $=0.03$; details and sources in the Supplementary Material):

$$
X_{\mathrm{An}}=0.92(0.07) \cdot \mathrm{Ca} \#_{\mathrm{melt}}+1.63(0.24) \cdot \mathrm{Al} \#_{\mathrm{melt}}+0.24(0.05) \cdot(\mathrm{molar} \mathrm{Ca} / \mathrm{Al})_{\mathrm{melt}}-0.54(0.06)(1)
$$

Test data $(n=36)$ from experimental studies on basalts from mid-ocean ridges and a continental hotspot with $X_{\mathrm{An}} \sim 0.6-0.9$ are reproduced well by equation $1\left(r^{2}=0.92\right.$; standard error $\left.=0.02\right)$, albeit with a slight offset to lower $X_{\mathrm{An}}$, possibly because of $\mathrm{Na}$ loss during some experiments (Fig. 2b; sources in the Supplementary Material).

\section{ORIGINS OF HIGH-ANORTHITE PLAGIOCLASE}

High- $X_{\text {An }}$ plagioclase has been described in lavas from many mid-ocean ridge segments and ocean islands (e.g., Lange et al., 2013). Here we apply our model to published Icelandic and MORB glass compositions, though our findings are likely to apply in other settings erupting $\mathrm{H}_{2} \mathrm{O}$-poor basalts. Equilibrium plagioclase $X_{\text {An }}$ predicted from Icelandic $(n=190)$ and MORB $(n$ = 1687) glass compositions collated by Shorttle and Maclennan (2011) and Gale et al. (2013), 
Preprint of a revised manuscript resubmitted to Geology and uploaded to EarthArXiv

112 respectively, are shown in Fig. 3; results were filtered for plagioclase saturation using a stability

113 criterion from Gale et al. (2014) (details in the Supplementary Material).

114 Predicted plagioclase $X_{\text {An }}$ correlates with melt $\mathrm{MgO}$ content and Ca\# in Icelandic and

115 MORB datasets (Figs. 3A and 3B), though high-Ca\# melts occur across a wide range of melt

$116 \mathrm{MgO}$ contents (8-11 wt.\%). Crucially, some glasses from both datasets return stable high- $X_{\mathrm{An}}$

117 compositions ( $n=33$ and 22, respectively). Although these glasses are at the limit of natural

118 variability in the case of MORB, their occurrence nonetheless substantiates rare observations of

119 equilibrium high- $X_{\mathrm{An}}$ in nature ( $X_{\mathrm{An}}$ up to 0.89 ; Natland et al., 1983). Icelandic glasses return

120 higher maximum $X_{\mathrm{An}}$ contents than MORB glasses (up to $X_{\mathrm{An}}=0.89$ and 0.85 , respectively),

121 likely reflecting differences in sampling density and mantle melting conditions.

122 As well as being associated with high melt $\mathrm{Ca \#}$ at any given melt $\mathrm{MgO}$ content (Figs. 3A

123 and $3 \mathrm{~B}$ ), high- $X_{\text {An }}$ plagioclase is typically associated with low melt $\mathrm{K}_{2} \mathrm{O}$ contents (often

$124<0.1$ wt.\%; Figs. 3C and 3D), recapitulating the incompatible-element-depleted character of

125 erupted high- $X_{\text {An }}$ plagioclase (Neave et al., 2014; Nielsen et al., 2020). Such high-Ca\#, low- $\mathrm{K}_{2} \mathrm{O}$

126 melts are commonly generated by shallow melting of refractory peridotites that have experienced

127 high degrees of prior melting (e.g., Grove et al., 1992; Shorttle and Maclennan, 2011). High- $X_{\text {An }}$

128 plagioclase is also associated with low melt $\mathrm{FeO}^{*}$ contents (total $\mathrm{Fe}$ as $\mathrm{FeO}$ ) at any given melt

$129 \mathrm{MgO}$ content (Figs 3E and 3F). This is particularly clear for Iceland, where low-FeO* primitive

130 melts $\left(\mathrm{FeO}^{*}<10 \mathrm{wt} . \%\right)$ from relatively refractory peridotites are predicted to be equilibrium in

131 with high- $X_{\mathrm{An}}$ plagioclase but high-FeO* primitive melts $(\mathrm{FeO} *>10$ wt.\%) from modally

132 enriched sources (pyroxenites sensu lato) are not predicted to be in equilibrium with plagioclase

133 of any composition (Fig. 3E). Refractory melts capable of crystallizing high- $X_{\text {An }}$ plagioclase thus

134 do not mix substantially with melts from modally enriched sources during ascent and are derived 
Preprint of a revised manuscript resubmitted to Geology and uploaded to EarthArXiv

135 from dominantly peridotitic sources (Shorttle and Maclennan, 2011); rare $\mathrm{K}_{2} \mathrm{O}$-rich melts in

136 equilibrium with high- $X_{\text {An }}$ plagioclase may have interacted with depleted harzburgites (Fig. 3D;

137 Nielsen et al., 2020). We hence argue that high- $X_{\text {An }}$ plagioclase crystals are the solid products of

138 melts from sources that have experienced high degrees of prior melting. In some cases, isotopic

139 depletions suggest that this melt extraction was ancient (Halldórsson et al., 2008; Nielsen et al.,

140 2020). Indeed, we speculate that high- $X_{\text {An }}$ plagioclase may be associated with ultra-depleted

141 sources recorded by some melt inclusions and abyssal peridotites (Sobolev and Shimizu, 1993;

142 Salters et al., 2011; Stracke et al., 2019), though closer integration of isotopic and major-element

143 observations is required to test this further.

\section{WIDESPREAD REFRACTORY MELTS AT DEPTH}

145 High- $X_{\text {An }}$ plagioclase occurs throughout the oceanic realm (Fig. 4). In Iceland, it is 146 especially well documented in the Eastern Volcanic Zone (Fig. 4A), where isotopically and

147 incompatible-element-depleted high- $X_{\text {An }}$ plagioclase may constitute $>30$ vol. $\%$ of lavas with

148 comparatively enriched isotopic and incompatible-element compositions (Halldórsson et al.,

149 2008). High- $X_{\text {An }}$ plagioclase has also been described in depleted picrites from Iceland's Northern

150 Volcanic Zone of Iceland, as well as in diverse basalts from Galápagos, Réunion and Kerguelen

151 (Fig. 4A). Overall, these observations suggest that refractory melts with depleted incompatible-

152 element compositions are more prevalent beneath ocean islands than the incompatible-element

153 enriched character of OIBs would otherwise imply (e.g., Stracke et al., 2019).

154 High- $X_{\text {An }}$ plagioclase crystals have been widely reported in plagioclase-rich MORBs

155 from slow- to intermediate-spreading mid-ocean ridges (Fig. 4B; Lange et al., 2013; Nielsen et

156 al., 2020). With a few notable exceptions (Fig. 4B; Natland et al., 1983), these high- $X_{\text {An }}$ contents

157 are found in crystal cores surrounded by more evolved rims and are out of equilibrium with their 
Preprint of a revised manuscript resubmitted to Geology and uploaded to EarthArXiv

158 carrier melts, mirroring observations from ocean islands that high-Ca\# melts from refractory

159 sources are probably more widespread at depth than suggested by erupted archives. Indeed, melt

160 inclusion entrapment pressures typically place high- $X_{\text {An }}$ plagioclase crystallization at or below

161 the Moho (Drignon et al., 2018), preventing the eruption of such plagioclase in many settings.

162 Recent experiments have also suggested that phase relations at >500 MPa may play a key role in

163 generating $X_{\mathrm{An}} \sim 0.9$ plagioclase (Ustunisik et al., 2022).

164

High- $X_{\text {An }}$ plagioclase crystals are found in lower crustal sections of the fast-spreading

165 Samail ophiolite in Oman (Fig. 4C; Browning, 1982), though elevated melt $\mathrm{H}_{2} \mathrm{O}$ contents likely

166 modify plagioclase-liquid equilibria in ophiolitic settings (Koepke et al., 2021). Despite its

167 relative scarcity, perhaps as a result of melt rock-reaction (Sanfilippo et al., 2020), $X_{\text {An }} \sim 0.8$

168 plagioclase does occur in crustal samples from the fast-spreading East Pacific Rise, slow-

169 spreading Mid-Atlantic Ridge and very slow-spreading Southwest Indian Ridge (Fig. 4D; Dick

170 et al., 2002; Lissenberg et al., 2013; Sanfilippo et al., 2019), suggesting that high-Ca\# melts

171 occur and contribute to crustal accretion throughout the global ridge system. Observations from

172 the East Pacific Rise also illustrate how magmatic processes bias records of chemical variability,

173 with high- $X_{\mathrm{An}}$ present at depth but absent from seafloor lavas as a consequence of filtering by

174 axial melt lenses.

175 In line with observations from melt incluions and abyssal peridotites, we argue that the

176 global occurrence of high- $X_{\text {An }}$ plagioclase demonstrates that refractory and incompatible

177 element-depleted melts occur widely in the uppermost mantle and lower crust. Two key

178 implications of this are that melts from refractory mantle sources are likely to play a greater role

179 in crustal accretion than currently recognized and that refractory (and feasibly depleted) domains

180 may be more prevalent in the upper mantle than previously thought. 
Preprint of a revised manuscript resubmitted to Geology and uploaded to EarthArXiv

\section{ACKNOWLEDGMENTS}

183 DAN acknowledges support from the Alexander von Humboldt Foundation (Germany) and 184 NERC (UK; NE/T011106/1). ON acknowledges support from the FWO (Belgium) through an 185 Odysseus grant.

\section{REFERENCES CITED}

Bowen, N.L., 1913, The melting phenomena of the plagioclase feldspars: American Journal of Science, v. 35, p. 577-599, doi:10.2475/ajs.s4-35.210.577.

Browning, P., 1982, The petrology, geochemistry and structure of the plutonic rocks of the Oman ophiolite: Open University, 404 p., doi:10.21954/ou.ro.0000de14.

Byerly, B.L., and Lassiter, J.C., 2014, Isotopically ultradepleted domains in the convecting upper mantle: Implications for MORB petrogenesis: Geology, v. 42, p. 203-206, doi:10.1130/G34757.1.

194 Chase, C.G., 1981, Oceanic island Pb: Two-stage histories and mantle evolution: Earth and Planetary Science Letters, v. 52, p. 277-284, doi:10.1016/0012-821X(81)90182-5.

Danyushevsky, L. V., 2001, The effect of small amounts of H2O on crystallisation of mid-ocean ridge and backarc basin magmas: Journal of Volcanology and Geothermal Research, v. 110,

Dick, H.J.B. et al., 2002, Primary silicate mineral chemistry of a 1.5-km section of very slow spreading lower ocean crust: ODP Hole 735B, Southwest Indian Ridge: Proceedings of the 
Preprint of a revised manuscript resubmitted to Geology and uploaded to EarthArXiv

202

203

204

205

206

207

208

209

210

211

212

213

214

215

216

217

218

219

220

221

222

Drignon, M.J., Nielsen, R.L., Tepley, F.J., and Bodnar, R.J., 2018, Upper mantle origin of plagioclase megacrysts from plagioclase-ultraphyric mid-oceanic ridge basalt: Geology, v. 47, p. 1-4, doi:10.1130/G45542.1.

Gale, A., Dalton, C.A., Langmuir, C.H., Su, Y., and Schilling, J.G., 2013, The mean composition of ocean ridge basalts: Geochemistry, Geophysics, Geosystems, v. 14, p. 489-518, doi:10.1029/2012GC004334.

Gale, A., Langmuir, C.H., and Dalton, C.A., 2014, The Global Systematics of Ocean Ridge Basalts and their Origin: Journal of Petrology, v. 55, p. 1051-1082, doi:10.1093/petrology/egu017.

Ghiorso, M.S., and Sack, R.O., 1995, Chemical mass transfer in magmatic processes IV. A revised and internally consistent thermodynamic model for the interpolation and extrapolation of liquid-solid equilibria in magmatic systems at elevated temperatures and pressures: Contributions to Mineralogy and Petrology, v. 119, p. 197-212, doi:10.1007/BF00307281.

Grove, T.L., Kinzler, R.J., and Bryan, W.B., 1992, Fractionation of Mid-Ocean Ridge Basalt (MORB), in Mantle Flow and Melt Generation at Mid-Ocean Ridges, Geophysical Monograph 71, Washington D.C., American Geophysical Union, p. 281-310, doi:0.1029/GM071.

Halldórsson, S.A., Óskarsson, N., Grönvold, K., Sigurdsson, G., Sverrisdottir, G., and Steinthórsson, S., 2008, Isotopic-heterogeneity of the Thjorsa lava-Implications for mantle sources and crustal processes within the Eastern Rift Zone, Iceland: Chemical Geology, v. 
Preprint of a revised manuscript resubmitted to Geology and uploaded to EarthArXiv 255, p. 305-316, doi:10.1016/j.chemgeo.2008.06.050.

224 Hofmann, A.W., 1997, Mantle geochemistry: the message from oceanic volcanism: Nature, v. $225 \quad 385$, p. 219-229, doi:10.1038/385219a0.

226

227

228

229

230

231

232

233

234

235

236

237

238

239

240

241

242

Holland, T.J.B., Green, E.C.R., and Powell, R., 2018, Melting of peridotites through to granites: a simple thermodynamic model in the system KNCFMASHTOCr: Journal of Petrology, v. 59, p. 881-900, doi:10.1093/petrology/egy048.

Koepke, J., Feig, S.T., Berndt, J., and Neave, D.A., 2021, Wet magmatic processes during the accretion of the deep crust of the Oman Ophiolite paleoridge: Phase diagrams and petrological records: Tectonophysics, v. 8, p. 229051, doi:10.1016/j.tecto.2021.229051.

Kohut, E.J., and Nielsen, R.L., 2003, Low-pressure phase equilibria of anhydrous anorthitebearing mafic magmas: Geochemistry, Geophysics, Geosystems, v. 4, p. 1-27, doi:10.1029/2002GC000451.

Lange, A.E., Nielsen, R.L., Tepley, F.J., and Kent, A.J.R., 2013, The petrogenesis of plagioclase-phyric basalts at mid-ocean ridges: Geochemistry, Geophysics, Geosystems, v. 14, p. 3282-3296, doi:10.1002/ggge.20207.

Lissenberg, C.J., MacLeod, C.J., Howard, K.A., and Godard, M., 2013, Pervasive reactive melt migration through fast-spreading lower oceanic crust (Hess Deep, equatorial Pacific Ocean): Earth and Planetary Science Letters, v. 361, p. 436-447, doi:10.1016/j.epsl.2012.11.012.

Maclennan, J., 2008a, Concurrent mixing and cooling of melts under Iceland: Journal of 
Preprint of a revised manuscript resubmitted to Geology and uploaded to EarthArXiv Petrology, v. 49, p. 1931-1953, doi:10.1093/petrology/egn052.

244 Maclennan, J., 2008b, Lead isotope variability in olivine-hosted melt inclusions from Iceland: Geochimica et Cosmochimica Acta, v. 72, p. 4159-4176, doi:10.1016/j.gca.2008.05.034.

246 247

Michael, P.J., 1995, Evidence from trace elements and $\mathrm{H}_{2} \mathrm{O}$ for regionally distinctive sources of depleted MORB: Implications for evolution of the depleted mantle: Earth and Planetary Science Letters, v. 131, p. 301-320, doi:10.1180/minmag.1994.58A.2.52.

Namur, O., Charlier, B., Toplis, M.J., and Vander Auwera, J., 2012, Prediction of plagioclasemelt equilibria in anhydrous silicate melts at 1-atm: Contributions to Mineralogy and Petrology, v. 163, p. 133-150, doi:10.1007/s00410-011-0662-z.

Natland, J.H., Adamson, A.C., Laverne, C., Melson, W.G., and O'Hearn, T., 1983, A Compositionally Nearly Steady-State Magma Chamber at the Costa Rica Rift: Evidence from Basalt Glass and Mineral Data, Deep Sea Drilling Project Sites 501, 504, and 505, in Initial Reports of the Deep Sea Drilling Project, 69, v. 53, p. 1689-1699, doi:10.2973/dsdp.proc.69.154.1983.

Neave, D.A., Maclennan, J., Hartley, M.E., Edmonds, M., and Thordarson, T., 2014, Crystal storage and transfer in basaltic systems: the Skuggafjöll eruption, Iceland: Journal of Petrology, v. 55, p. 2311-2346, doi:10.1093/petrology/egu058.

Neave, D.A., Namur, O., Shorttle, O., and Holtz, F., 2019, Magmatic evolution biases basaltic records of mantle chemistry towards melts from recycled sources: Earth and Planetary Science Letters, v. 520, p. 199-211, doi:10.1016/j.eps1.2019.06.003. 
Preprint of a revised manuscript resubmitted to Geology and uploaded to EarthArXiv

263 Nielsen, R.L., Ustunisik, G., Lange, A.E., Tepley, F.J., and Kent, A.J.R., 2020, Trace Element 264 and Isotopic Characteristics of Plagioclase Megacrysts in Plagioclase Ultraphyric Basalts 265 (PUB): Geochemistry, Geophysics, Geosystems, v. 21, p. 1-24, 266 doi:10.1029/2019GC008638.

267 Salters, V.J.M., Mallick, S., Hart, S.R., Langmuir, C.E., and Stracke, A., 2011, Domains of 268 depleted mantle: New evidence from hafnium and neodymium isotopes: Geochemistry, 269 Geophysics, Geosystems, v. 12, doi:10.1029/2011GC003617.

270 Sanfilippo, A., Dick, H.J.B., Marschall, H.R., Lissenberg, C.J., and Urann, B., 2019,

271 Emplacement and High-Temperature Evolution of Gabbros of the $16.5^{\circ} \mathrm{N}$ Oceanic Core 272 Complexes (Mid-Atlantic Ridge): Insights Into the Compositional Variability of the Lower 273 Oceanic Crust: Geochemistry, Geophysics, Geosystems, v. 20, p. 46-66, 274 doi:10.1029/2018GC007512.

275 Sanfilippo, A., MacLeod, C.J., Tribuzio, R., Lissenberg, C.J., and Zanetti, A., 2020, Early-Stage 276 Melt-Rock Reaction in a Cooling Crystal Mush Beneath a Slow-Spreading Mid-Ocean 277 Ridge (IODP Hole U1473A, Atlantis Bank, Southwest Indian Ridge): Frontiers in Earth $278 \quad$ Science, v. 8, p. 1-21, doi:10.3389/feart.2020.579138.

279 Sanfilippo, A., Salters, V.J.M., Sokolov, S.Y., Peyve, A.A., and Stracke, A., 2021, Ancient 280 refractory asthenosphere revealed by mantle re-melting at the Arctic Mid Atlantic Ridge: 281 Earth and Planetary Science Letters, v. 566, p. 116981, doi:10.1016/j.epsl.2021.116981.

282 Shorttle, O., and Maclennan, J., 2011, Compositional trends of Icelandic basalts: Implications for 283 short-length scale lithological heterogeneity in mantle plumes: Geochemistry, Geophysics, 
Preprint of a revised manuscript resubmitted to Geology and uploaded to EarthArXiv Geosystems, v. 12, p. 1-32, doi:10.1029/2011GC003748.

285 Sobolev, A. V., and Shimizu, N., 1993, Ultra-depleted primary melt included in an olivine from 286 the Mid-Atlantic Ridge: Nature, v. 363, p. 151-154, doi:10.1038/363151a0.

287 Stracke, A., 2021, A process-oriented approach to mantle geochemistry: Chemical Geology, v. 288 184, p. 120350, doi:10.1016/j.chemgeo.2021.120350.

289 Stracke, A., Genske, F., Berndt, J., and Koornneef, J.M., 2019, Ubiquitous ultra-depleted 290 domains in Earth's mantle: Nature Geoscience, v. 12, p. 851-855, doi:10.1038/s41561-019$291 \quad$ 0446-z.

292 Ustunisik, G.K., Nielsen, R.L., and Walker, D., 2022, The Missing Magmas of MOR: Insights 293 from Phase Equilibrium Experiments on Plagioclase Ultraphyric Basalts: Geochemistry, 294 Geophysics, Geosystems, v. 23, p. e2021GC009943, doi:10.1029/2021gc009943. 
Preprint of a revised manuscript resubmitted to Geology and uploaded to EarthArXiv
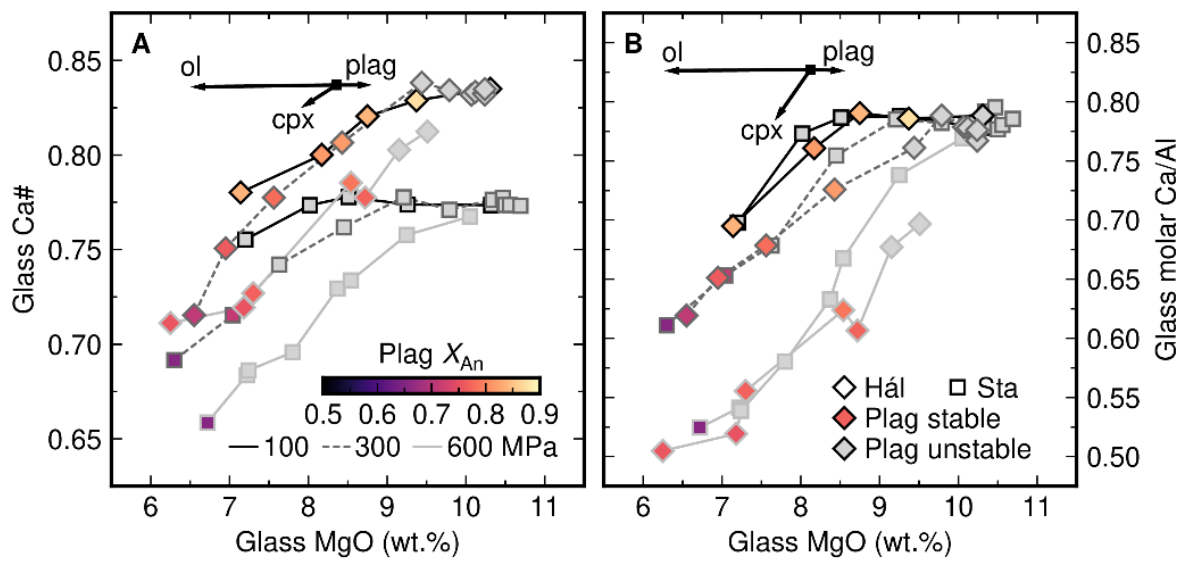

297 Figure 1. Plagioclase-liquid equilibria in synthetic analogues of the high-Ca\# Háleyjabunga (Hál)

298 and low-Ca\# Stapafell (Sta) lavas from Iceland (where Ca\# = molar $\mathrm{Ca} /(\mathrm{Ca}+\mathrm{Na})$ ) summarized in

299 terms of glass $\mathrm{MgO}$ content versus (A) glass Ca\# and (B) glass molar $\mathrm{Ca} / \mathrm{Al}$. New results at 100

300 and $600 \mathrm{MPa}$ are presented alongside results at $300 \mathrm{MPa}$ from Neave et al. (2019). Plagioclase

301 crystallizes earlier and with a higher anorthite content $\left(X_{\mathrm{An}}\right.$, where $X_{\mathrm{An}}=$ molar $\left.\mathrm{Ca} /(\mathrm{Ca}+\mathrm{Na}+\mathrm{K})\right)$

302 from high-Ca\# melts. Vectors show the crystallization of $5 \mathrm{wt}$ \% olivine (ol), clinopyroxene

303 (cpx) and plagioclase (plag) according to Danyushevsky (2001). 
Preprint of a revised manuscript resubmitted to Geology and uploaded to EarthArXiv
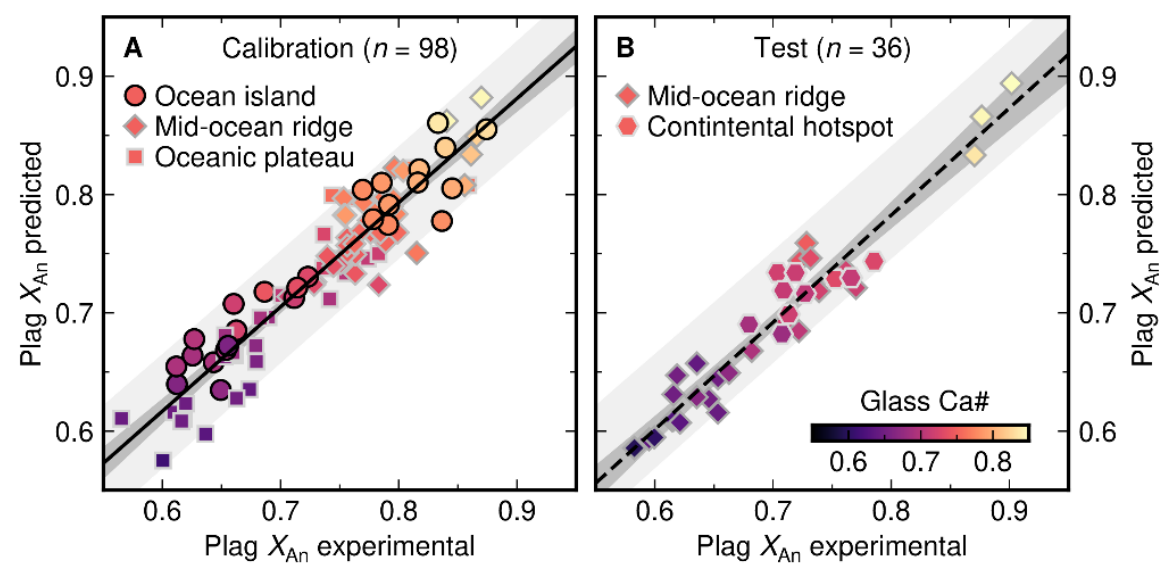

305 Figure 2. (A) Performance of the multiple linear regression (Eq 1) used to predict plagioclase

306 (plag) anorthite content $\left(X_{\mathrm{An}}\right)$ as a function melt composition. The black line shows a regression

307 through calibration data from experimental studies on basalts from an ocean island, mid-ocean

308 ridges and an oceanic plateau. Dark and pale grey envelopes show 95\% confidence and

309 prediction intervals, respectively. (B) Performance of Eq 1 on test data from mid-ocean ridges

310 and a continental hotspot. The dashed black line and dark grey envelope show a regression

311 through the test data and its 95\% confidence interval, respectively; the pale grey envelope shows

312 the $95 \%$ prediction interval of Eq 1. Details and sources in the Supplementary Material. 

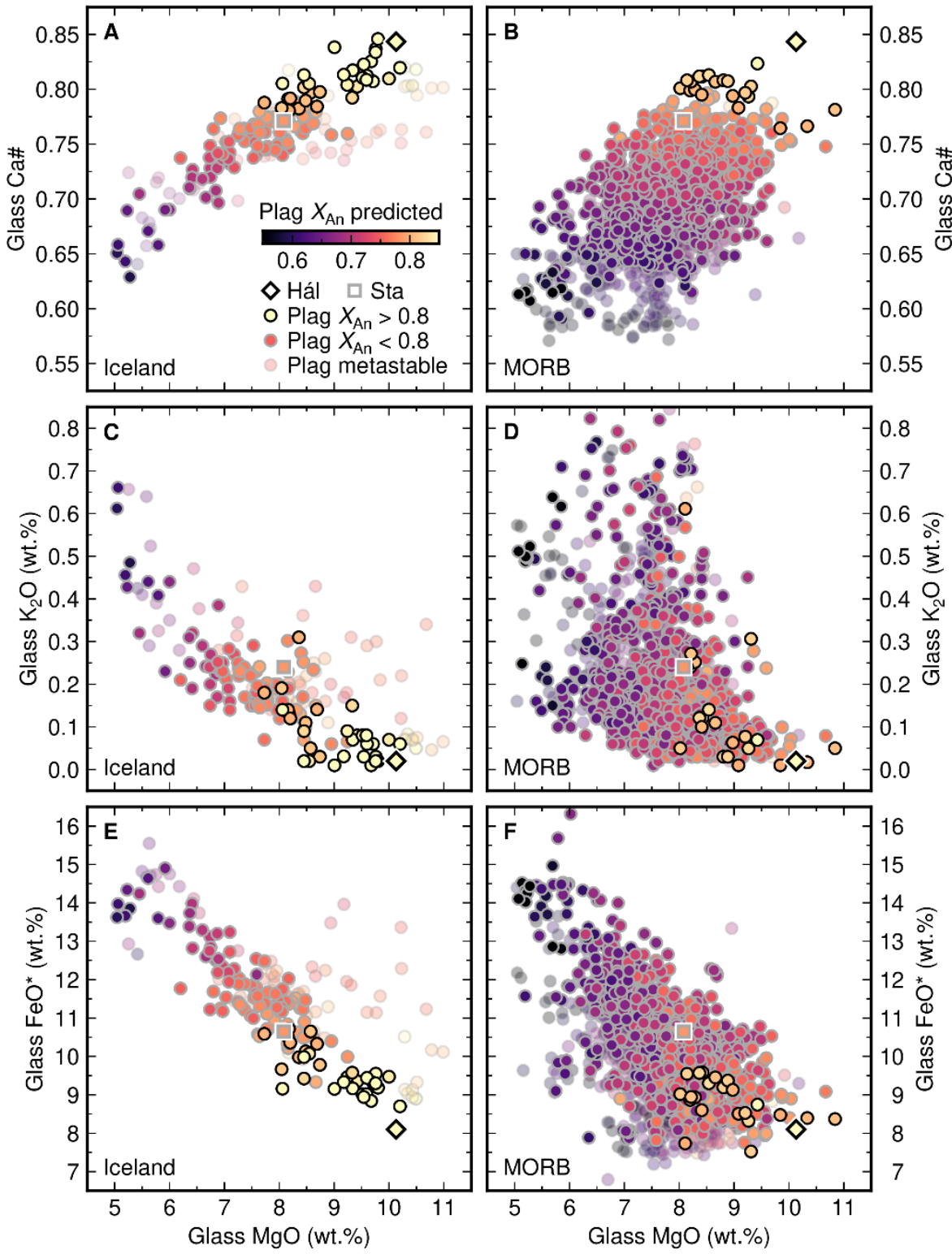

314 Figure 3. Plagioclase (plag) anorthite contents $\left(X_{\text {An }}\right)$ predicted to be in equilibrium with Icelandic

315 (A, C and E) and MORB (B, D and F) glasses from Shorttle and Maclennan (2011) and Gale et

316 al. (2013), respectively. The evolution of glass compositions is shown for elements emphasizing

317 fractionation $(\mathrm{MgO})$, degree of source enrichment $\left(\mathrm{K}_{2} \mathrm{O}\right.$ and $\left.\mathrm{FeO}^{*}\right)$ and control on plagioclase-

318 liquid equilibria (Ca\#). Glass compositions that fail a plagioclase stability criterion from Gale et

319 al. (2014) are transparent and those in equilibrium with high- $X_{\mathrm{An}}$ plagioclase $\left(X_{\mathrm{An}}>0.8\right)$ are

320 outlined in black; glasses from Háleyjabunga (Hál) and Stapafell (Sta) are highlighted. 
Preprint of a revised manuscript resubmitted to Geology and uploaded to EarthArXiv
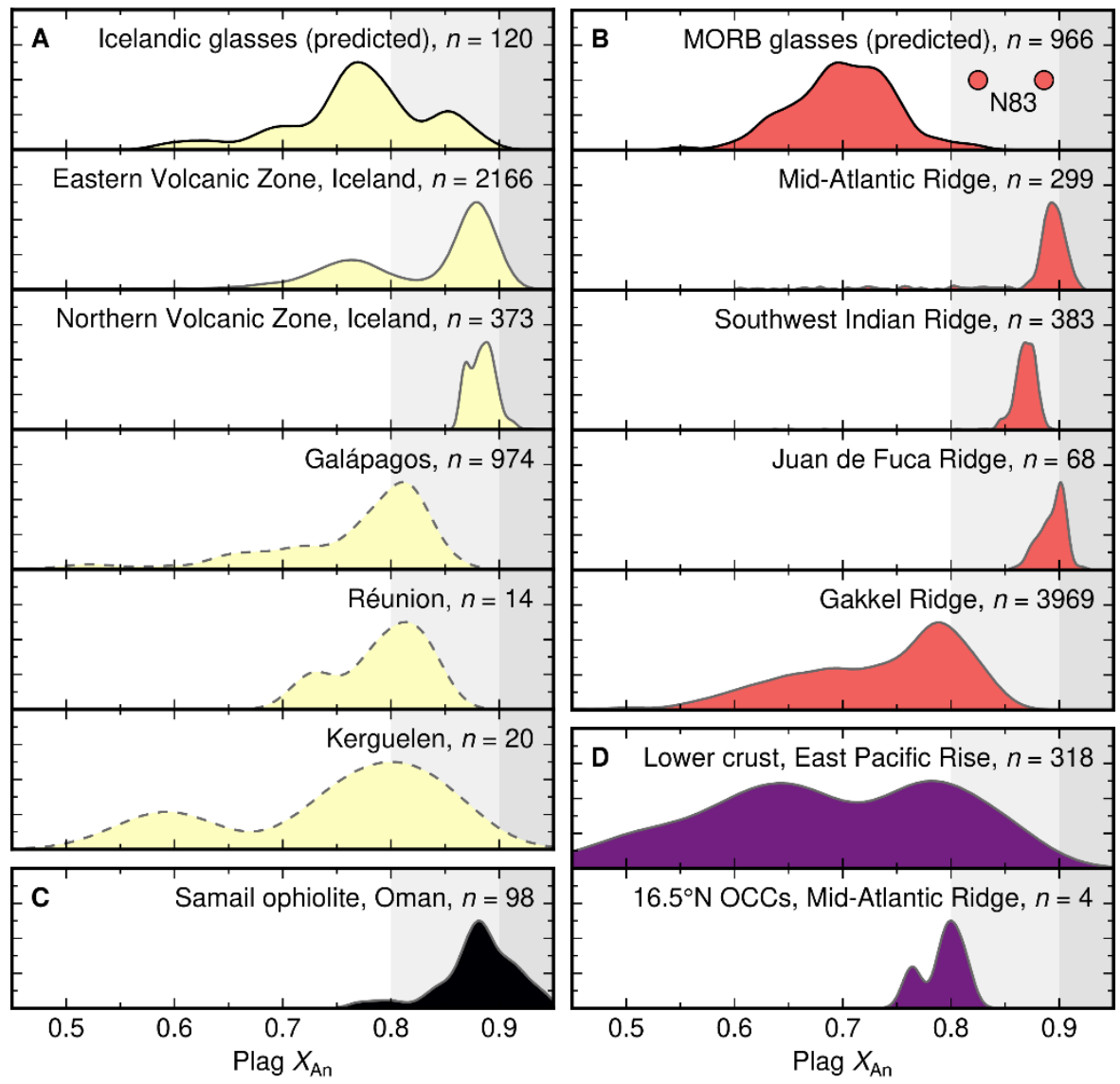

322 Figure 4. Kernel density estimates summarizing how plagioclase (plag) anorthite contents $\left(X_{\text {An }}\right)$

323 predicted to be in equilibrium with (A) Icelandic and (B) MORB glasses from Shorttle and

324 Maclennan (2011) and Gale et al. (2013), respectively, compare with natural plagioclase

325 compositions from (A) ocean island basalts, (B) mid-ocean ridge basalts (MORB), (C) the

326 Samail ophiolite, Oman, and (D) the oceanic crust (OCCs, oceanic core complexes). Rare high-

$327 X_{\text {An }}$ rims from MORB are highlighted (Natland et al., 1983; N83). Sources in the Supplementary 328 Material. 